\title{
Difference of Het Re Level In Thalassemia $\beta$ Minor And Iron Deficiency Anemia
}

\author{
Yustisia Amalia* \\ Universitas Dr. Soetomo Surabaya, Indonesia \\ *yusti.amalia@yahoo.com
}

\begin{abstract}
The most common diseases found with peripheral blood morphological features of hypochromic microcytic anemia are iron deficiency anemia and thalassemia. Hypochrome micrositer is a morphological description of red blood cells with MCV values smaller than normal $(<80 \mathrm{fl})$ and $\mathrm{MCH}$ smaller than normal values $(<27 \mathrm{pq})$. This morphological picture can be found in the condition of iron deficiency anemia and thalassemia. There are several markers for the assessment of $\mathrm{Hb}$ content in reticulocytes, including Ret-He. Ret-He, which can be measured by the latest automated hematological analysis, is considered to reflect the iron content in reticulocytes. This research is an observational analytic study using case control measurement method, during July to September 2019 at the Surabaya Medical Centre Hospital. The population was students who were admitted to the University of Dr. Soetomo who came for complete blood count examination. The subjects were students with MCV <80 fl, MCH <27 pq. Subjects who met the inclusion criteria then continued with the calculation of the Mentzer Index and RDW Index, ferritin serum examination using the ECLIA method, hemoglobin electrophoresis examination with micro capillary electrophoresis. By consecutive sampling, 42 samples were obtained, of which 21 subjects diagnosed with iron deficiency anemia and 21 subjects diagnosed with beta thalassemia minor were examined for their Ret-He levels using the flowsitometric method which were then analyzed statistically. From 21 iron deficiency anemia patients it was found that the average Ret-He value was 30.64 (6.08) pg and from 21 patients with beta minor thalassemia it was found that the average Ret-He value was $25.63(6,72) \mathrm{pg}$. The results of the unpaired t-test for both groups obtained $\mathrm{p}=0.016$. By using the ROC curve obtained the Ret-He cutoff value in distinguishing cases of iron deficiency anemia with thalassemia was $27.30 \mathrm{pg}$ with a sensitivity of $90.5 \%$ and specificity of $71.4 \%$.

From the results of the study concluded that there was a significant difference between the levels of Ret-He in patients with iron deficiency anemia with thalassemia beta minor patients with a cut-off value of $27.30 \mathrm{pg}$
\end{abstract}

Keywords: Iron Deficiency Anemia, Thalassemia, Ret-He 


\section{STRADA Jurnal Ilmiah Kesehatan}

DOI: $10.30994 /$ sjik.v9i2.515

ISSN: 2252-3847 (print); 2614-350X (online)

Vol.9 No.2 November 2020 Page. 1635-1641

\section{BACKGROUND}

The most common diseases found with peripheral blood morphological features of hypochromic microcytic anemia are iron deficiency anemia and thalassemia. Hypochrome micrositer is a morphological description of red blood cells with MCV values smaller than normal $(<80 \mathrm{fl})$ and $\mathrm{MCH}$ smaller than normal values $(<27 \mathrm{pq}) .{ }^{1,2,3}$ Iron deficiency anemia is an anemia caused by low iron for eritropoesis ${ }^{1,4,5,6}$, while Thalasemia is genetic disorder which cause decrease globin chain synthesis ${ }^{7,8,9}$.

Thalasemia is widespread in areas in mainland China in border like Muangthai,Laos,Kamboja with a frequency of 50-60\% and also spread in southest area with lower frequency. In Indonesia, expected in 3-5\% ,same as Malaysia and Singapura, ${ }^{7,9}$.

Reticulosit Haemoglobin measure reflects a dynamic erythropoesis process in bone marrow ${ }^{10}$. Ret-He is an iron indeks and reflect availability of cellular iron ${ }^{10}$. Ret-He got a collaboration with iron deficiency and a sign for iron deficiency in child and baby, adult blood donation, geriatric, pregnant woman and chronic kidney disease patient in hemodialysis ${ }^{11,12,13}$. erythrocytes and reticulocytes can uses to help differentiate thalassemia and iron deficiency anemia ${ }^{14}$.

This research to differentiate the value of Ret He in thalassemia and iron deficiency anemia in RS Surabaya Medical Center Surabaya.

\section{METHODS}

This research is an analytical research with design case control. One-time observation to obtain data on Ret-He levels from minor beta thalassemia and iron deficiency anemia patients at Surabaya Medical Center Surabaya Hospital. The population is a student accepted at Dr. Soetomo University who comes for a complete blood test.

Patients who meet inclusion criteria such as 1) hypochrotic micrositics (MVC $<80$ fl, $\mathrm{MCH}<27 \mathrm{pg}$ ) 2) minor beta Thalasemia patients who have confirmed laboratory examination 3) iron deficiency anemia patients who have confirmed laboratory examination 4) maximum age 18 years 5) patients willing to be research samples and sign informed consent. The subject meets the inclusion criteria followed by the calculation of Mentzer Index and RDW Index, examination of serum Feritin by ECLIA method, examination of Electrophoresis Hemoglobin with micro capillary electrophoresis. Consecutive sampling of 42 samples, of which 21 subjects were diagnosed with iron deficiency anemia and 21 subjects with minor beta thalasemia diagnoses. Patients who had had blood transfusions in the last 3 months, received iron supplementation, and suffered from other systemic diseases were exclusivity from this study.

Edta venous blood samples of 42 patients were examined from July 2019 to September 2019. Checks are performed with Sysmex XN-1000 which has been done quality control before. Complete blood analysis is done by automatic cell counting with flowcytometry principle. The data taken is in the form of complete blood and Ret He levels.

Analysis of research data was conducted using SPSS by performing bivariate analysis using un paired $\mathrm{T}$ for data with normal distribution and Mann Whitney test for data that was not distributed normally. Receiver-operating characteristic (ROC) curves are performed to determine the cut point of Ret-He levels in distinguishing cases of Iron Deficiency Anemia with Thalasemia Beta minor. P value $<0.05$ is said to be statistically meaningful

\section{RESULTS}

The data analysis was conducted on 42 patients with a male gender of $4(9.5 \%)$ with an average age of 17.95 years standard deviation of 0.49 and the median age is 18 years with 


\section{STRADA Jurnal Ilmiah Kesehatan}

DOI: $10.30994 /$ sjik.v9i2.515

ISSN: 2252-3847 (print); 2614-350X (online)

Vol.9 No.2 November 2020 Page. 1635-1641

the lowest age is 16 years and the highest age is 18 years. The characteristics of the research sample can be seen in the table below.

Table 1 Sample Characteristic

\begin{tabular}{|c|c|c|c|c|}
\hline Variable & $\mathbf{N}$ & $\%$ & Mean(SD) & Median(Min-Max) \\
\hline Age (years) & & & $17,95(0,49)$ & $18(16-18)$ \\
\hline \multicolumn{5}{|l|}{ Sex } \\
\hline Male & 4 & 9,5 & & \\
\hline Female & 38 & 90,5 & & \\
\hline \multicolumn{5}{|l|}{ Ethnic } \\
\hline Jawa & 10 & 23,8 & & \\
\hline Toba & 9 & 21,4 & & \\
\hline Melayu & 8 & 19,0 & & \\
\hline Mandailing & 5 & 11,9 & & \\
\hline Tionghoa & 3 & 7,1 & & \\
\hline Karo & 2 & 4,8 & & \\
\hline Simalungun & 2 & 4,8 & & \\
\hline Banjar & 1 & 2,4 & & \\
\hline Nias & 1 & 2,4 & & \\
\hline Toraja & 1 & 2,4 & & \\
\hline
\end{tabular}

Median hemoglobin $(\mathrm{Hb})$ levels of iron deficiency anemia and thalasemia were found to be $9.60 \%$ and $9.80 \%$ (p 0.0037). Median MCV value and mentzer index of minor beta thalassemia patients were lower than iron deficiency anemia $(61.59 ; 12.30)$ while the median RDW value of thalasemia patients was higher (16.60).

Tabel 2. Data on measurement of Hemoglobin levels, number of RBC, MCV value, RDW value, Mentzer Index, RDW Index, Ferrite Levels in Iron Deficiency Anemia patients and Minor Beta Thalasemia patients

\begin{tabular}{|c|c|c|c|}
\hline Variable & $\begin{array}{c}\text { Iron Deficiency } \\
\text { Anemia } \\
\text { Mean(SD) } \\
\text { Median(Min-Max) }\end{array}$ & $\begin{array}{c}\text { Thalasemia Beta } \\
\text { Minor } \\
\text { Mean(SD) } \\
\text { Median(Min-Max) }\end{array}$ & P Value \\
\hline $\mathrm{Hb}$ value $(\mathrm{gr} \%)$ & $9,60(8,40-10,00)$ & $9,80(8,20-10,70)$ & $0,037 * *$ \\
\hline $\mathrm{RBC}\left(\mathrm{juta} / \mathrm{mm}^{3}\right)$ & $3,77(3,56-3,96)$ & $5,13(4,56-5,81)$ & $<0,001 * *$ \\
\hline MCV (fL) & $74,09(2,68)$ & $61,59(4,30)$ & $<0,001 *$ \\
\hline RDW & $12,60(11,50-14,20)$ & $16,60(11,60-18,40)$ & $<0,001 * *$ \\
\hline Mentzer Index & $19,80(18,30-21,10)$ & $12,30(9,70-12,90)$ & $<0,001 * *$ \\
\hline RDW Index & $324,76(29,55)$ & $193,80(19,64)$ & $<0,001 *$ \\
\hline Feritin $(\mathrm{mcg} / \mathrm{L})$ & $8,00(3,00-10,00)$ & $87,00(40,00-179,00)$ & $<0,001 * *$ \\
\hline
\end{tabular}

*T- unpaired test* *Mann Whitney Test

There was a significant difference between Ret-He levels in iron deficiency anemia patients and minor beta thalasemia patients, where Ret-He levels in Thalasemia Beta Minor patients $(25.63 \pm 6.72 \mathrm{pg})$ were lower compared to Ret-He levels in iron deficiency anemia patients $(30.64 \pm 6.08 \mathrm{pg})$ [p 0.016]. Image 1 


\section{STRADA Jurnal Ilmiah Kesehatan}

DOI: $10.30994 /$ sjik.v9i2.515

ISSN: 2252-3847 (print); 2614-350X (online)

Vol.9 No.2 November 2020 Page. 1635-1641

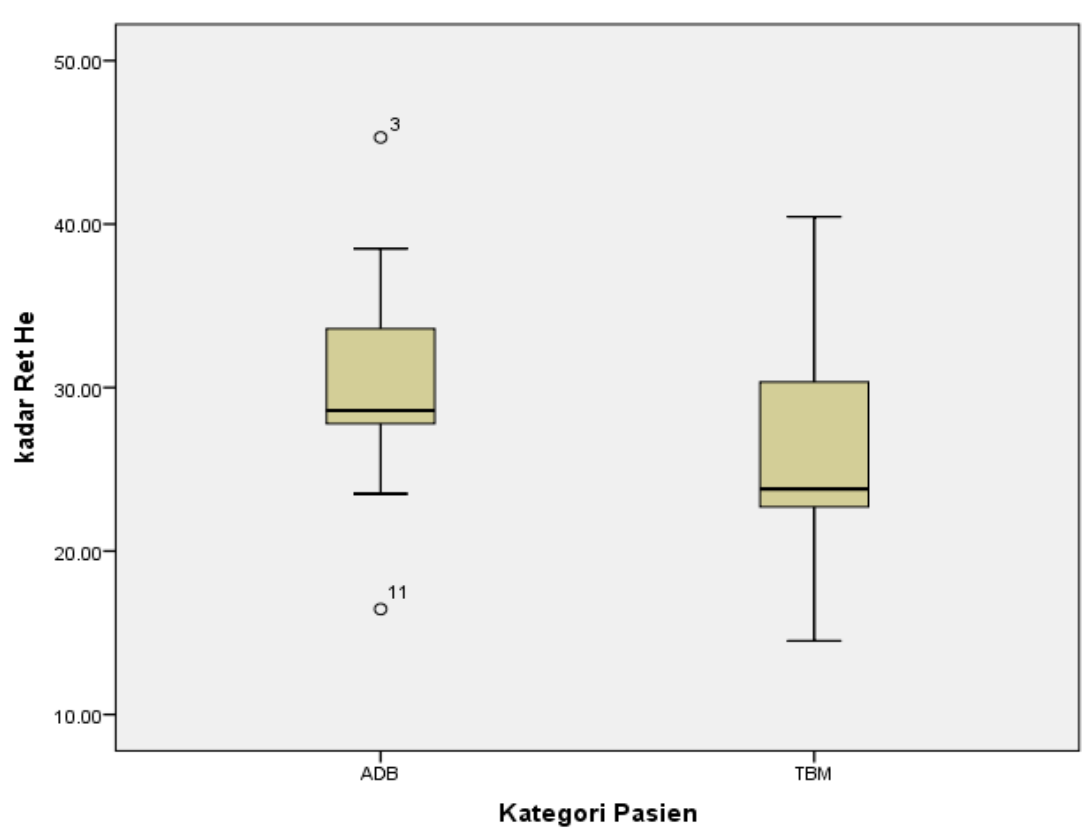

Image 1. Comparison of Ret-He levels in iron deficiency anemia patients with minor beta thalasemia patients

The value of Ret-He discrimination in distinguishing cases of iron deficiency anemia with minor beta thalasemia was assessed by the Receiver Operating Characteristic (ROC) method and found AUC 74.6\%, with a confidence interval of $0.586-0.906$ (IK 95\%, $\mathrm{p}=0.006$ ) with moderate quality discrimination. From this analysis, the ret-he cut point value was $27.30 \mathrm{pg}$ with a sensitivity of $90.5 \%$ and a specificity of $71.4 \%$.

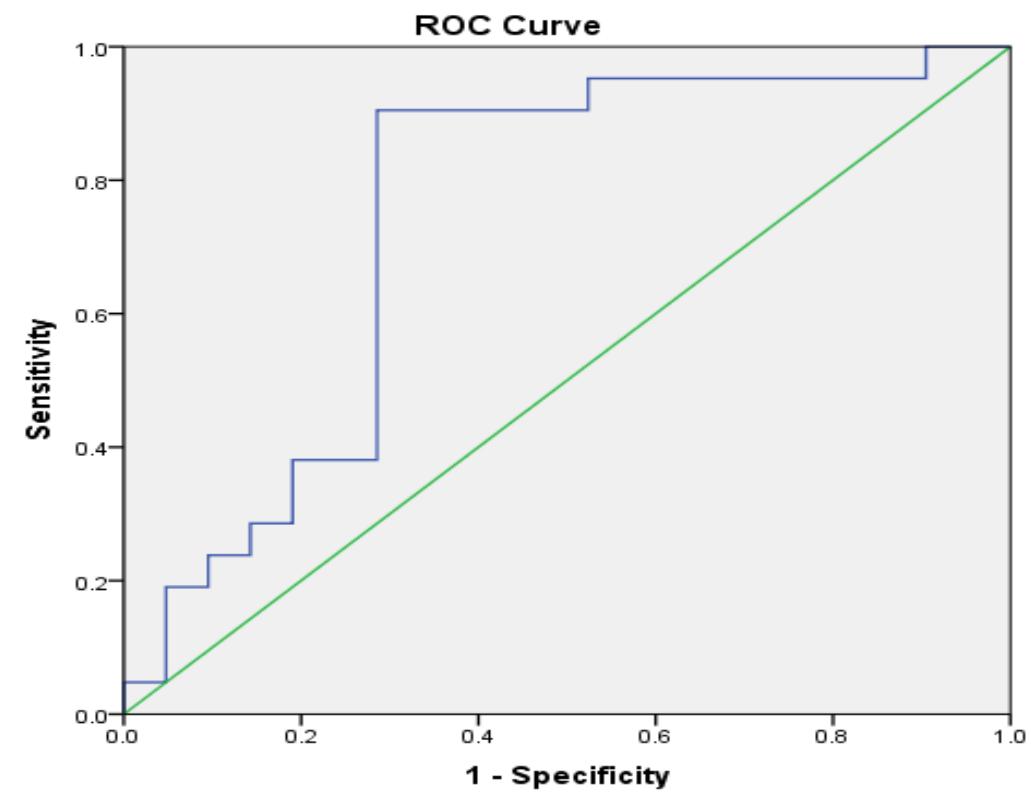

Image 2 Receiver-operating characteristics curve analysis to assess Ret-He performance in distinguishing cases of iron deficiency anemia with minor beta thalasemia 


\section{STRADA Jurnal Ilmiah Kesehatan}

DOI: $10.30994 /$ sjik.v9i2.515

ISSN: 2252-3847 (print); 2614-350X (online)

Vol.9 No.2 November 2020 Page. 1635-1641

\section{DISSCUSION}

This research is a case control study that aims to find out the role of Ret-He levels in distinguishing cases of iron deficiency anemia with beta minor thalasemia. In general, iron deposits are reduced or lost before people develop anemia. Therefore, diet and iron recycled erythrocytes must meet the demands for the production of erythrocytes. If iron loss continues, the newly produced erythrocytes will decrease hemoglobin, causing the amount of iron provided by erythrocytes to decrease. Unlike thalasemia, an increase in the amount of erythrocytes is not produced in a state of iron deficiency to compensate for the decrease in intracellular hemoglobin levels. For this reason, reticulocytosis usually does not exist. In the absence of major bleeding, iron deficiency anemia generally develops slowly for months or years ${ }^{15}$.

Thalasemia is a genetic blood disorder, caused when the body makes fewer healthy red blood cells and fewer hemoglobins than normal. Hemoglobin is a protein in red blood cells that carries oxygen to all tissues of the body. Hemoglobin usually consists of two $\alpha-$ and two globins. The nature of thalasemia syndrome is associated with reduced or absence of synthesis of any of these two chains. The $\alpha$-thalasemia is lower than $\beta$-thalasemia and usually shows no symptoms ${ }^{16}$.

Most current hemoglobinopathy screening methods include high performance liquid chromatography (HPLC), hemoglobin electrophoresis, PCR mutation screening, and DNA testing. All of these methods result in higher project costs and require special instrumentation and trained technicians. In addition, currently various indexes and formulas of red blood cells (RBC) have been designed to distinguish between talasemia and IDA and its sensitivity and specificity are presented in various articles ${ }^{16}$.

From the study conducted found significant differences between Hemoglobin levels, MCV values, RDW values, Mentzer Index and Ferrite levels in iron deficiency anemia patients with minor beta thalasemia patients. This is in line with previous research that conducted research on the use of new indexes for hematological parameters to distinguish cases of iron deficiency anemia with cases of thalasemia beta minor17. The results found significant differences between, hemoglobin levels, MCV values, $\mathrm{MCH}$ values, ferritin levels between patients with iron deficiency anemia and minor beta thalasemia patients with a $p<0.001$ value. However, there was no significant difference between the RDW value of patients with iron deficiency anemia and minor beta thalasemia patients with a value of $\mathrm{p}=0.94^{17}$.

From the study, there was a significant difference between Ret-He levels in iron deficiency anemia patients and minor beta thalasemia patients with a value of $p=0.016$, where Ret-He levels in minor beta thalasemia patients were lower than those with iron deficiency anemia. This is in line with research on efficacy from the use of new parameters in distinguishing cases of minor $\beta$-thalasemia, iron deficiency anemia, megaloblastic anemia and aplastic anemia18. The study found that Ret-He levels in minor beta thalasemia patients were lower $(20.92 \pm 1.5 \mathrm{pg})$ compared to patients with iron deficiency anemia (21.0 \pm 9.1$)$. This is because Ret-He exhibits recent changes in the synthesis of hemoglobin in reticulocytes. Ret He measurement is a direct assessment of the merging of iron in haemoglobin. This parameter is highly sensitive and specific due to the short and meaningful life span of reticulocytes for early diagnosis of iron deficiency erythrooiesis ${ }^{18}$.

Reticulocytes parameters are better for detecting iron-deficient erythrooiesis than red blood cell indexes. Reticulocytic maturation assessment is beneficial in establishing an anemia mechanism and effective assessment of erythrooiesis19. Reticulocytes are released 


\section{STRADA Jurnal Ilmiah Kesehatan}

DOI: $10.30994 /$ sjik.v9i2.515

ISSN: 2252-3847 (print); 2614-350X (online)

Vol.9 No.2 November 2020 Page. 1635-1641

from the marrow 18 to 36 hours before their last maturation; they provide a real-time assessment of the functional status of erythropoiesisi ${ }^{20}$.

Ret-He represents the latest change in hemoglobin synthesis in reticulocytes. Ret He measurement is a direct assessment of the merging of iron in hemoglobin14. This parameter is very sensitive and specific due to the short life span of reticulocytes and is very meaningful for early diagnosis of iron-deficient erythrooiesis ${ }^{21}$.

The discrimination performance of Rer-He Levels in distinguishing cases of iron deficiency anemia was presented with an AUC value of 74.6\% (IK 95\% $=0.586-0.906$ ) indicating moderate quality discrimination. In this study obtained a cut point Ret-He in distinguishing cases of iron deficiency anemia with beta minor thalasemia is $27.30 \mathrm{pg}$. The results of this study show differences with previous research on the parameters of hemoglobin reticulocytes equivalent in iron deficiency anemia patients22. From the study obtained a cut off value of $28.5 \mathrm{pg}$ to diagnose iron deficiency anemia patients. This difference lies in the expected end result and the population used. This led to this study having a lower cut point value of Ret-He levels than other studies.

\section{CONCLUSION}

There was a significant difference in ret-he levels between patients with iron deficiency anemia and minor beta thalasemia patients with a value of $p=0.016$. The cut off value of Hemoglobin reticulocytes in distinguishing cases of iron deficiency anemia with minor beta thalasemia patients is $27.85 \mathrm{pg}$ with a sensitivity of $90.5 \%$ and specificity of $71.4 \%$. Hemoglobin reticulocytes should be included in a complete hematological examination. More research is needed on Ret-He for its application with other diseases.

\section{REFERENCES}

1. Andrews NC. 2009. Iron deficiency and related disorders. In: Greer JP,Foerster J,Rodgers GM, Paraskevas F, Glader B, Arber DA et al,editor. Wintrobe's Clinical Hematology 12th ed. Philadelphia:Lippincott Williams and Wilkins:.p.810-34

2. Andrews NC. 1999. Disorders of iron metabolism.New England Journal of Medicine; 341(26):1986-95.

3. Bakta ,I Made. 2007. Anemia Hipokromik Mikrositer dengan Gangguan Metabolisme besi dalam Hematologi Klinik Ringkas ,Penerbit Buku Kedokteran EGC,Cetakan I: 2628.

4. Hilman RS, Kenneth AR \& Henry M. 2005. Iron Deficiency Anemia in Hematology in Clinical Practice,McGraw-Hill: 1-20

5. World Health Organization, Centers for Disease Control and Prevention; 2005. Assessing the iron status of populations: report of a joint World Health Organization/Centers for Disease Control and Prevention technical consultation on the assessment of iron status at the population level, Geneva, Switzerland, 6-8 April 2004. Geneva

6. Ciesla B. 2007. The Microcytic Anemias in Hematology in practice,F.A.Davis Company ,USA: 65-95.

7. Weatherall DJ. 2006. Disorders of globin synthesis : The Thalasemias in Williams Hematology seventh edition, McGrill-Hill:633-721.

8. Caterina Borgna Pignattinand Renzo Galanello. 2004. Thalasemias and Related Disorders in Wintrobe Clinical Hematology, $11^{\text {th }}$ ed, Lippincott Williams \& Wilkins:1319-1365. 


\section{STRADA Jurnal Ilmiah Kesehatan}

DOI: $10.30994 /$ sjik.v9i2.515

ISSN: 2252-3847 (print); 2614-350X (online)

Vol.9 No.2 November 2020 Page. 1635-1641

9. Hoffbrand AV, Peltit J.E \& Moss PAH. 2005. Anemia Hipokrom dan penimbunan besi dalam Kapita Selekta Hematologi,Edisi 4, Penerbit Buku Kedokteran EGC,Jakarta,2527.

10. Brugnara C, Schiller B,Moran J. 2006. Reticulocyte hemoglobin equivalent (Ret-He) and assessment of iron deficient states. Clin. Lab. Haem 2006;28: 303-8.

11. Torsvik IK, Markestad T, Ueland PM, Nilsen RM, Midttun O, Bjørke Monsen AL. 2013. Evaluating iron status and the risk of ane- mia in young infants using erythrocyte parameters. Pediatr Res;73:214-20

12. Semmelrock MJ, Raggam RB, Amrein K, Avian A, Schallmoser K, Lanzer G, et al. 2012. Reticulocyte hemoglobin content allows early and reliable detection of functional iron deficiency in blood donors. Clin Chim Acta;413:678-82

13. Joosten E, Lioen P, Brusselmans C, Indevuyst C, Boeckx N. 2013. Is analysis of the reticulocyte haemoglobin equivalent a useful test for the diagnosis of iron deficiency anaemia in geriatric patients? Eur J Intern Med.;24:63-6.

14. Urrechaga E, Borque L, Escanero JF. Erythrocyte and Reticulocyte Parameters in Iron Deficiency and Thalassemia. J Clin Lab Anal. 2011;25(3):223-8.

15. Miller JL. Iron Deficiency Anemia: A Common and Curable. Cold Spring Harb Perspect Med. 2013;3(7):1-13.

16. Kabootarizadeh L, Jamshidnezhad A, Koohmareh Z, Ghamchili A. Differential Diagnosis of Iron-Deficiency Anemia from $\beta$-Thalassemia Trait Using an Intelligent Model in Comparison with Discriminant Indexes. ACTA Inf Med. 2019;27(2):78-84.

17. Jahangiri M, Rahim F, Malehi AS. Diagnostic performance of hematological discrimination indices to discriminate between $\beta$ eta thalassemia trait and iron deficiency anemia and using cluster analysis: Introducing two new indices tested in Iranian population. Sci Reports Nat J. 2019;9:1-13.

18. Thomas L, Franck S, Messinger M, Linssen J, Thome M, Thomas C. 2005. Reticulocyte hemoglobin measurement- comparison of two methods in the diagnosis of ironrestricted erythropoiesis. ClinChem Lab Med. 43(11):1193-1202. PMID: 16232085

19. Oustamanolakis P, Koutroubakis IE, Messaritakis I, Kefalogiannis G, Niniraki M KE. Measurement of reticulocyte and red cell indices in the evaluation of anemia in inflammatory bowel disease. J Crohns Colitis. 2011;5(4):295-300.

20. Wysocka J, Turowski D. New reticulocyte indices and their utility in hematologic diagnosis. Pol MerkurLekarski. 2000;8(49):498-502.

21. Eguchi A, Tsuchiya K, Tsukada M, Nitta K. Clinical usefulness of reticulocyte hemoglobin equivalent (RET-He) in patients at the pre-dialysis stage and in patients on peritoneal dialysis. Nihon JinzoGakkai Shi. 2010;52(2):132-40.

22. Toki Y, Ikuta K, Kawahara Y, Niizeki N, Kon M, Enomoto M. Reticulocyte hemoglobin equivalent as a potential marker for diagnosis of iron deficiency. Int J Hematol. 201 